\section{Influence of Plant Bioregulators on Pecan Flowering and Implications for Regulation of Pistillate Flower Initiation}

\author{
Bruce W. Wood ${ }^{1}$ \\ U.S. Department of Agriculture, Agricultural Research Service, Southeastern \\ Fruit and Tree Nut Research Laboratory, Byron, GA 31008-0087
}

Additional index words. growth regulators, fruiting, flowering, alternate bearing, irregular bearing, profit, production, flowers, staminate flowers

\begin{abstract}
Mitigation of alternate bearing (AB) through regulation of floral initiation of pistillate flowers is central to improving cropload management of pecan [Carya illinoinensis (Wangenh.) K. Koch] trees and orchards. The present study examines the influence of key bioregulators \{i.e., an auxin [as $B$-napththaleneacetic acid (NAA)], a cytokinin [6-benylamino purine (6-BA)], an ethylene generator (ethephon), and an auxin transport inhibitor $[2,3,5$-triiodobenzoic acid (TIBA)]\} on subsequent season pistillate flowering. Gibberellic acid (i.e., $\mathbf{G A}_{3}$ ) and NAA inhibited, whereas prohexadione-calcium (P-Ca; calcium 3-oxido-5-oxo-4-propionylcyclohex-3-enecarboxylate), ethephon, and BA + TIBA promoted floral initiation when topically applied to canopies before the kernel filling stage of seed development. These bioregulators exhibit potential for integration into a bioregulator-based strategy to mitigate pecan $A B$ by selective and timely use in "off" or "on" cycle years, depending on the bioregulator. Field studies provide evidence that a "cytokinin-gibberellin balance," with partial modulation by auxin and ethylene, acts in the endogenous primordial environment of floral meristems as a "second-level signal" regulating a key step in a three-step process for initiation of pistillate flowers in pecan. This establishes a new model for explaining pistillate flower initiation in pecan and a basis for designing future research on the control and management of pistillate flowering and $\mathrm{AB}$.
\end{abstract}

Natural selection operating over evolutionary time has produced pecan as an economically important species that exhibits pronounced biennial-like alternations in seed production as a strategy for ensuring long-term reproductive success. This year-to-year variation in pistillate flowering, and subsequent cropload, is termed $\mathrm{AB}$. Although AB-linked variation in pistillate flowering likely increases individual fitness in natural habitats, it is also a major impediment to greater horticultural domestication and is the primary biology-based impediment to horticultural enterprises (Wood, 1991). Excessive yearto-year variability in pistillate flowering limits tree and orchard profitability, thus adversely affecting producers, processors, and consumers through instabilities in nutmeat supply, quality, and price (Sparks, 1974, 1975; Wood, 1991). Although the specific processes regulating $\mathrm{AB}$ in pecan remain ambiguous, the trait tightly

Received for publication 19 Jan. 2011. Accepted for publication 28 Mar. 2011.

The assistance of James Stuckey and Kirby Moncrief for data collection and Buddy Murph for orchard management and harvesting is gratefully acknowledged.

Use of trade names does not imply endorsement of the products named or criticism of similar ones not named.

${ }^{1}$ To whom reprint requests should be addressed; e-mail bruce.wood@ars.usda.gov. therefore likely to involve an autonomous flowering pathway as a key step in its floral initiation process (Wood et al., 2003). Like with many other tree-fruit species (Schmidt et al., 2009), florally induced bud primordia on heavy cropload trees (i.e., "on" year of $\mathrm{AB}$ cycle) are likely exposed to different phytohormonal environments than are primordia of induced buds on light cropload trees (i.e., "off" year of AB cycle). This raises the possibility that timely application of phytohormones or bioregulators to tree canopies might alter the phytohormonal environment of primordia in such a way as to enable control of pistillate flowering by pecan farmers.

The efficacy and horticultural potential of bioregulators to control the "on" and "off" flowering phases of pecan trees has not been reported despite considerable circumstantial evidence that endogenous phytohormones are involved in floral initiation processes (Barnett and Mielke, 1981; Rohla et al., 2007a, 2007b; Wood, 1982, 1984a, 1984b, 1991, 2003; Wood and McMeans, 1981; Wood et al., 2003). A variety of natural and synthetic bioregulators are efficacious for control of floral initiation processes in several polycarpic perennial crops and involve timely use of floral promoters [generally ethephon and P-Ca and NAA or $\mathrm{GA}_{4}$ in certain situations (Looney et al., 1985)] in "on" years to promote return flowering the following "off" year and use of floral inhibitors [gibberellic acids $\left(\mathrm{GA}_{3,4,7}\right)$ (Greene, 2000) and auxin analogs (e.g., NAA) in certain cases] in "off" years to decrease subsequent year flowering. It is unknown whether these promoters and inhibitors similarly affect pecan flowering in "on" and "off" years.

Commercial pecan production enterprises need better horticultural tools for managing flowering and AB. Successful development and exploitation of such tools depend on acquiring better understanding of floral initiation processes operating in pecan. This study assesses certain promising bioregulators for activity and/or influence on pecan flowering and examines how their interactions influence pistillate flower initiation. It reports that several synthetic bioregulators possess potential as horticultural tools for controlling pistillate flowering and $\mathrm{AB}$ in pecan and, based on observed influence of bioregulators on flowering, presents a "three-level signaling" model explaining regulation of pistillate flower initiation in pecan trees.

\section{Materials and Methods} (1.e. hormones in regulation of floral initiation (i.e. the production of meristems of clearly recognizable flower primordia and includes all preceding reactions that are required if flowers are to be initiated).

Regulation of floral initiation in trees depends on processing of environmental and/or endogenous cues (Amasino, 2010) with initiation in most large-seeded temperate woody perennial angiosperms being primarily controlled by endogenous cues consistent with processing through an autonomous flowering pathway involving phytohormones (Wilkie et al., 2008). Floral initiation in pecan is

\section{General orchard characteristics}

A series of experiments were conducted between 2002 and 2010 using orchards located at Byron, GA, a humid climatic zone (lat. $+32^{\circ} 39^{\prime} 54^{\prime \prime} \mathrm{N}$, long. $+83^{\circ} 44^{\prime} 31^{\prime \prime} \mathrm{W}$ ) with an average elevation of $\approx 156 \mathrm{~m}(509 \mathrm{ft})$. The dominant orchard soil is a Faceville sandy loam soil (fine, Kaolintic, thermic Typic Kandiudult soil). The site has a freeze-free growing period of $\approx 280 \mathrm{~d}$ with annual precipitation of $\approx 1.3 \mathrm{~m}$ (51 inches). The test cultivars were Sumner, Oconee, or Pawnee, grafted to an open-pollinated 'Elliott' seedling rootstock. 
Orchards were managed according to the Georgia Extension Services guidelines for pests, fertilizers, etc. (Hudson et al., 2007). Trees also received subsurface drip irrigation with drip emitters rising to the soil surface at 1-m intervals to supplement tree water needs. Parallel irrigation lines ran the length of tree rows, positioned $\approx 1.2 \mathrm{~m}$ on either side of tree trunks. Drip emitters delivered water at 3.78 $\mathrm{L} \cdot \mathrm{h}^{-1}$ for $\approx 8$ to $12 \mathrm{~h} \cdot \mathrm{d}^{-1}$, depending on water needs, throughout the growing season. Irrigation lines were within an herbicide strip maintained in a vegetation-free state using glyphosate (Monsanto, St. Louis, MO). Trees received annual broadcast applications of nitrogen, potassium, phosphorous, magnesium, and calcium as needed, based on previous July leaf analysis, at principal leaf development growth stage "11" (Finn et al., 2007). Canopies also received foliar sprays of micronutrients (zinc, nickel, copper, manganese, iron, and boron) during canopy expansion (growth stage "11-17") each spring. Orchard management included routine foliar sprays of pesticides to control pecan scab [Fusicladosporium effusum (Winter)] disease and various arthropod pests. Pest management practices produced fruits with little pecan scab damage and little or no fruit drop or fruit damage by arthropod pests.

\section{Study 1: Influence of gibberellic acid, prohexadione-calcium, and ethephon on flowering}

This experiment tested the hypothesis that flowering in pecan can be manipulated by timely applications of GAs, P-Ca (an inhibitor of GA synthesis) and ethephon (a generator of ethylene). Efficacy testing used either 25year-old 'Pawnee' trees or 5-year-old 'Oconee' trees in an "on" year of crop production.

Expt. 1: Influence of bioregulators and partial defoliation on return flowering of "off'"-phase 'Pawnee' shoots. This study used individual 'Pawnee' trees exhibiting an overall light cropload (less than $\approx 5 \%$ of terminals fruiting). Treatments were 1) nontreated control [i.e., the control (included Silwet L- $77^{\circledR}$, an organosilicone surfactant, at $0.025 \% \mathrm{v} / \mathrm{v}$ used in all plant growth regulator treatments at this rate, Helena Chemical Co., Memphis, TN); 2) $\mathrm{GA}_{3}$ (ProGibb ${ }^{\circledR}$ at $50 \mathrm{mg}$ a.i./L; Valent BioSciences Corporation, Libertyville, IL); 3) 6-BA [N-(phenyl-methyl)-1Hpurine-6-amine at $50 \mathrm{mg}$ a.i./L)]; 4) $\mathrm{GA}_{4+7}$ plus BA (Promalin ${ }^{\circledR}$, at $50 \mathrm{mg}$ a.i./L, Valent BioSciences Corporation); 5) P-Ca at $500 \mathrm{mg}$ a.i./L; and 6) partial defoliation (i.e., all foliage on the shoot were manually removed except for the apical-most leaflet remaining for each compound leaf on the terminal shoot). Application of bioregulators was through three biweekly (i.e., every 2 weeks) foliar sprays beginning early July and extending to mid-August. The study consisted of the six aforementioned treatments structured as a randomized complete block (RCB) consisting of five single-tree blocks $(n=30)$. A set of 15 sun-exposed terminal shoots served as the experimental unit; thus, there were 90 experimental shoots per tree. The terminal shoot of pecan is the primary growth unit and axis of the tree's basic architectural unit that also includes secondary axes of zero to four lateral shoots. Measured parameters were 1) percentage of subsequent season terminal shoots displaying pistillate flowers; and 2) number of pistillate flowers per flower cluster at spring anthesis. Statistical analysis was by least squares analysis of variance (ANOVA) at $P \leq 0.05$ with treatment means separated by Student's $t$ test.

Expt. 2: Influence of gibberellin on flowering of whole trees.

Phase 1: Gibberellin 3 and return flowering of 'Oconee' trees. This study was initiated using 'Oconee' trees with a light cropload (less than $\approx 5 \%$ of terminals fruiting). Treatments were 1) nontreated control (i.e., the control included Silwet L-77, an organosilicone surfactant, at $0.025 \% \mathrm{v} / \mathrm{v}$ used in all plant growth regulator treatments at this rate; Helena Chemical Co.); and 2) $\mathrm{GA}_{3}$ (ProGibb ${ }^{\circledR}$ at $100 \mathrm{mg}$ a.i./L; Valent BioSciences Corporation). Treatment application involved three biweekly foliar sprays beginning the second week of June and extending to early July (i.e., six applications). Treated trees were in their fourth leaf. The study consisted of the two aforementioned treatments structured as a RCB consisting of 10 singletree experimental units $(n=20)$. Measured parameters were mean number of pistillate flowers or young fruit per tree at anthesis the next spring. Statistical analysis was by least squares ANOVA at $P \leq 0.05$.

Phase 2: Gibberellin 3 and return flowering of 'Pawnee' trees. This study assesses the effect of $\mathrm{GA}_{3}$ on pistillate flower production of 'Pawnee' trees in their "off" year when the overall orchard cropload was very light (less than $\approx 5 \%$ terminals fruiting), thus likely ensuring a relatively large "on" year for pistillate flower production at anthesis the next spring. Experimental design was a RCB using two treatments: 1) nontreated control (i.e., included Silwet surfactant as described previously, being in both treatments); and 2) $\mathrm{GA}_{3}$ (ProGibb at $50 \mathrm{mg}$ a.i./L). Influence on subsequent year (i.e., the "on" year) flowering was assessed in consequence of spraying (through an air-blast sprayer) tree canopies with $\mathrm{GA}_{3}$ during early morning to achieve leaf soak. The first application was the first week of August, $\approx 12$ weeks after full bloom (AFB), and repeated biweekly for a total of three applications ending in early September, $\approx 21$ to $31 \mathrm{~d}$ before fruit ripening.

Treatments were arranged as a RCB with eight single-tree blocks $(n=24)$. Experimental units consisted of single 'Pawnee' trees blocked by relative cropload. Measured parameters were 1) percentage of terminal shoots displaying pistillate flowers at anthesis the spring after treatment; 2 ) average number of pistillate flowers per terminal; and 3 ) mean number of pistillate flowers per flowering cluster. A randomly selected population of 20 terminal shoots per tree per treatment was used for measurement of relevant parameters. Measurements were made at anthesis the following spring. Statistical analysis was performed on parameters by two-way least squares ANOVA at $P \leq 0.05$.

Expt. 3: Influence of prohexadionecalcium on flowering of whole trees. The second study assessed the effect of P-Ca (Apogee ${ }^{\circledR}$ ) on pistillate flower production. It was initiated when $\approx 25$-year-old $\mathrm{AB}$ 'Pawnee' trees were in a moderate "on" year $(\approx 60 \%$ terminals fruiting), thus ensuring an "off" year for pistillate flower production at anthesis the next spring. Trees were treated three times at weekly intervals with one of five P-Ca concentrations (i.e., 0, 62.5, 125, 250 , and $500 \mathrm{mg}$ a.i./L). Timing of treatment application incorporated two distinctly different seed development stages. These were during the liquid endosperm stage before initiation of kernel filling versus cotyledon development after initiation of kernel filling. Initiation of kernel filling was considered to be at the gel stage of seed development when the inner surface of the liquid-filled endosperm coenocyte (the large liquid-filled central vacuole) exhibits a noticeable gelatinous layer of cells [i.e., the stage in which endosperm cellularization is initiated by the formation of radial microtubular systems at the surface of the endosperm nuclei, just before cell wall formation of the first alveolus structures that eventually grow in a centripetal manner, producing cell files oriented toward the center of the central vacuole of the endosperm until it is completely cellularized and seed cotyledons are filled (Olsen, 2001)]. Pre-kernel filling treatments began $\approx 4$ weeks (mid-July) before initiation of kernel filling followed by retreatment at 3 weeks and again at 2 weeks. Post-kernel filling treatments began at the time of initiation of kernel filling (i.e., $\approx 13$ Aug.), with applications again 1 week and 2 weeks later.

Experimental design was a RCB with four blocks of five continuous variable P-Ca treatments at two fruit development stages, thus giving 10 treatments $(n=40)$. Treatment application was through an air-blast sprayer (at $935 \mathrm{~L} \cdot \mathrm{ha}^{-1}$ ) to all portions of the tree canopy during early morning to ensure leaf soak and bioregulator uptake. Assessment of treatment effects on pistillate flower production was the next spring at anthesis, an "off" year, by assessing the percentage of terminal shoots displaying pistillate flower clusters. Data were analyzed using curvilinear regression.

Expt. 4: Influence of prohexadionecalcium and ethephon on flowering of whole trees. Results from the described Phase 2 study led to a study testing efficacy of 1) P-Ca [a GA metabolic inhibitor; calcium 3-oxido5-oxo-4-propionylcyclohex-3-enecarboxylate (Apogee); BASF Corporation, Research Triangle Park, NC, at $500 \mathrm{mg}$ a.i./L]; 2) ethephon [(2-chloroethyl)phosphonic acid, Ethrel ${ }^{\circledR}$ at $100 \mathrm{mg}$ a.i./L; Bayer CropScience, Inc., Calgary, Alberta, Canada]; and 3) "P-Ca plus ethephon" (i.e., "Apogee + Ethrel") as potential floral promoters in young pecan trees. Foliar applications were 1 June, 21 June, and again 14 July (i.e., 3, 6, and 9 weeks post-full bloom). Treatment of 'Oconee' trees was through an 
air-blast spray when trees were in their fifth leaf.

The experimental design consisted of the four aforementioned treatments structured as a RCB containing 10 blocks $(n=40)$. Experimental units consisted of single-tree experimental units blocked by cropload. Measured parameters were 1) percentage of terminal shoots exhibiting pistillate flowers (based on a random sampling of 20 shoots); and 2) average number of pistillate flowers per terminal shoot. Measurements were made at anthesis the next spring. Statistical analysis was performed on parameters by twoway least squares ANOVA at $P \leq 0.05$. Mean separation for main effects and interaction using Student's $t$ test.

\section{Study 2: Influence of cytokinin and auxin on flowering}

Expt. 1: Influence of benylamino purine, triiodobenzoic acid, and naphthaleneacetic acid on flowering of individual terminal shoots when applied in the "on" phase. This study was initiated when overall orchard cropload was relatively heavy $(\approx 60 \%$ terminals fruiting) for $\approx 25$-year-old 'Pawnee' trees. Treatments were 1) nontreated control (i.e., the control included Silwet L- 77 at $0.025 \% \mathrm{v} / \mathrm{v}$ used in all plant growth regulator treatments at this rate); 2) 6-BA) [or $\mathrm{N}$-(phenyl-methyl)- $1 \mathrm{H}$ purine-6-amine, at $50 \mathrm{mg}$ a.i./L]; 3) NAA (KSalt Fruit Fix ${ }^{\circledR}$ at $10 \mathrm{mg}$ a.i./L); 4) TIBA (at 100 mg a.i./L); and 5) and TIBA + BA. Application of treatments occurred as three biweekly foliar sprays beginning the first week of July and extending to mid-August. It consisted of the five aforementioned treatments structured as a RCB of five single-tree blocks $(n=25)$. A set of 15 sun-exposed terminal shoots served as the experimental unit. Measured parameters were 1) percentage of new terminal shoots displaying pistillate flowers; and 2) mean number of pistillate flowers per flower cluster at anthesis the next spring. Statistical analysis was by least squares ANOVA at $P \leq 0.05$. Mean separation is by Student's $t$ test at $P=0.05$.

Expt. 2: Influence of benylamino purine, triiodobenzoic acid, and naphthaleneacetic acid on flowering of trees. This experiment tested the hypothesis that return flowering in pecan is able to be manipulated through treatment of "on"-phase tree canopies with cytokinin, auxin, or an auxin inhibitor. Testing was done using 8-year-old 'Sumner' trees in an "on" crop year. Experiment initiation was when the overall orchard cropload was moderate $(\approx 40 \%$ to $50 \%$ of terminals fruiting) and efficacy evaluation was the next spring at anthesis. The experimental design was a RCB of seven discrete variable treatments. Treatments were 1) nontreated control (with Silwet L-77 at $0.025 \% \mathrm{v} / \mathrm{v}$ in all treatments); 2) cytokinin [6-BA or N-(phenyl-methyl)-1Hpurine-6-amine; a synthetic cytokinin; formulated as $\mathrm{MaxCel}^{\circledR}(1.9 \% \mathrm{BA})$ and applied at $50 \mathrm{mg}$ a.i./L)]; 3) auxin [NAA, a synthetic auxin formulated as K-Salt Fruit Fix (AMVAC, Los Angeles, CA), applied at $10 \mathrm{mg}$ a.i./L]; 4) auxin transport inhibitor TIBA at $100 \mathrm{mg}$ a.i./L; Sigma, St. Louis, MO); and 5) cytokinin plus auxin transport inhibitor ("MaxCel + TIBA").
Treatment application was with a hand-gun power sprayer during early morning to achieve leaf soak. The first application was 5 June and again for five more applications at 2-week intervals for a total of six applications. Immediately after spraying the entire tree canopy, 15 "on" terminal shoots (i.e., bearing fruit) and 15 "off" terminal shoots (i.e., not bearing fruit) were randomly selected in the canopy periphery and tagged for subsequent year evaluation.

The experimental design consisted of the five aforementioned treatments structured as a RCB with 10 single-tree blocks $(n=50)$. Experimental units were single trees blocked by cropload. Measured parameters were 1) number of staminate flower groups per previous season terminal shoot; 2) number of pistillate flower clusters arising from both terminal and lateral shoots origination in the previous season's terminal shoot; and 3) total number of pistillate flowers (i.e., florets) produced by the pistillate flower population associated with "2." Parameters were measured for both the "on" and "off" shoot populations at anthesis the next spring. Statistical analysis was performed on parameters by twoway least squares ANOVA at $P \leq 0.05$. Mean separation was by two-way least squares ANOVA at $P \leq 0.05$ using Student's $t$ test.

\section{Results and Discussion}

\section{Study 1: Influence of gibberellic acid, prohexadione-calcium, and ethephon on flowering}

Expt. 1: Influence of bioregulators and partial defoliation on return flowering of "off"'-phase 'Pawnee' shoots. Treatment of terminal shoots with certain bioregulators reduced floral initiation based on observation of pistillate flowers at anthesis the next spring (Table 1). Shoots previously "off" (also in an "off" tree) flowered at a rate of $\approx 65 \%$ (i.e., nontreated control) with partially defoliated (manually) shoots flowering at only $1 \%$, indicating that foliage contributes one or more floral inducing factors. Shoots treated the previous season with $\mathrm{GA}_{3}$ or $\mathrm{GA}_{4+7}$ plus $\mathrm{BA}$ were largely vegetative the next spring, exhibiting only $26 \%$ and $29 \%$, respectively, as many flowers as the control. Either BA or P-Ca alone did not influence the percentage of flowering terminal shoots. Bioregulators also influenced the number of florets per floral cluster on those shoots that did flower. Control shoots and PCa-treated shoots produced 4.4 florets per floral cluster, but BA slightly reduced florets per cluster, and both $\mathrm{GA}_{3}$ and $\mathrm{GA}_{4+7}$ plus $\mathrm{BA}$ substantially reduced florets per cluster. Thus, not only did GAs reduce the percentage of shoots flowering, but also the number of florets per shoot cluster. Taken together, it appears $\mathrm{GA}_{3}$, and $\mathrm{GA}_{4+7}$ in combination, and possibly $\mathrm{GA}_{4}$ or $\mathrm{GA}_{7}$ independently, inhibit floral initiation when applied the previous year during the period of floral induction within pecan buds. This indicates that GAs likely act as floral inhibitors in pecan, and P-Ca exhibits efficacy through inhibition of GA biosynthesis.

It appears that amount of foliage per shoot affects floral initiation. Because treatment trees returned with a heavy "on" crop, and nonstructural shoot carbohydrates were not measured, it is unknown whether this foliage effect is the result of energy reserves available to bud meristems or to dependence of phytohormones otherwise produced by foliage. Regardless, leaves produced one or more floral promoters during the early stages of floral initiation, and results are consistent with phytohormone regulation. This indicates that reproductively induced primordia depend on a leaf originating phloem mobile promoter for continuation of floral initiation processes and raises questions regarding amount of leaf area required for normal floral induction and initiation. It appears that up to a point, the greater the number of compound leaves and leaf area per shoot, the greater the likelihood of subsequent year flowering and the greater the number of florets per pistillate flower cluster; however, excessive leaf area results in absence of pistillate flowering (Wood et al., 2004; Wood, unpublished observations).

Expt. 2: Influence of gibberellin 3 on flowering of whole trees.

Phase 1: Gibberellin 3 and return flowering of 'Pawnee' trees. Canopy treatment of young "off" year 'Oconee' trees with $\mathrm{GA}_{3}$ during June and early July markedly reduced number of pistillate flowers per tree at anthesis the next spring (Table 2); thus, treatment with $\mathrm{GA}_{3}$ led to production of only $32 \%$ as much fruit per tree as the nontreated control. This supports a conclusion from Expt. 1 above that $\mathrm{GA}_{3}$ inhibits pistillate flower initiation in pecan and is especially active

Table 1. Influence of treating “off”-phase 'Pawnee' terminal shoots with foliar sprays of plant bioregulators [gibberellic acid $\left(\mathrm{GA}_{3}\right.$ ProGibb at $50 \mathrm{mg}$ a.i./L), prohexadione-calcium (P-Ca; Apogee; at $500 \mathrm{mg}$ a.i./L), gibberellin $\mathrm{A}_{4+7}$ and $\mathrm{N}^{6}$-benzyladenine (Promalin) at $50 \mathrm{mg}$ a.i./L), and $\mathrm{N}^{6}$-benzyladenine (BA, at $50 \mathrm{mg}$ a.i./L)], and partial defoliation (only the apical-most leaflet of each compound leaf remaining) of terminals on pistillate flower bloom the next spring. ${ }^{\mathrm{z}}$

\begin{tabular}{lcc}
\hline Treatment & $\begin{array}{c}\text { Percentage of terminal shoots } \\
\text { displaying pistillate flowers (\%) }\end{array}$ & $\begin{array}{c}\text { Number of pistillate flowers } \\
\text { per flowering terminals (no.) }\end{array}$ \\
\hline Control & $65 \mathrm{a}^{\mathrm{z}}$ & $4.4 \mathrm{a}^{\mathrm{y}}$ \\
Partial defoliation & $1 \mathrm{~b}$ & $0.7 \mathrm{~d}$ \\
$\mathrm{GA}_{3}$ & $17 \mathrm{~b}$ & $1.4 \mathrm{~cd}$ \\
$\mathrm{BA}$ & $56 \mathrm{a}$ & $2.9 \mathrm{~b}$ \\
$\mathrm{GA}$ & $19 \mathrm{~b}$ & $1.7 \mathrm{c}$ \\
$\mathrm{P}-\mathrm{Ca}$ & $59 \mathrm{a}$ & $4.4 \mathrm{a}$ \\
\hline
\end{tabular}

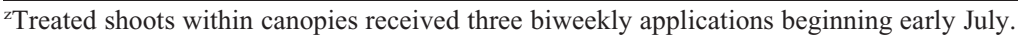

${ }^{y}$ Analysis of variance by least squares means with means within a column followed by the same letter are not significantly different $P=0.05$ by Student's $t$ test. 
Table 2. Influence of foliar sprays of gibberellic acid $\left(\mathrm{GA}_{3}\right.$ at $50 \mathrm{mg}$ a.i./L; ProGibb) on subsequent season production of pistillate flowers of 'Oconee' and 'Pawnee' pecan trees. ${ }^{\text {' }}$

\begin{tabular}{|c|c|c|c|c|}
\hline Treatment & $\begin{array}{l}\text { Fruit per } \\
\text { tree (no.) }\end{array}$ & $\begin{array}{l}\text { Terminal shoots } \\
\text { flowering }(\%)\end{array}$ & $\begin{array}{l}\text { Avg number of } \\
\text { pistillate flowers } \\
\text { per terminal (no.) }\end{array}$ & $\begin{array}{c}\text { Pistillate flowers } \\
\text { per flowering } \\
\text { terminal (no.) }\end{array}$ \\
\hline \multicolumn{5}{|l|}{ Oconee } \\
\hline Control & $44 \mathrm{a}^{\mathrm{y}}$ & - & - & - \\
\hline $\mathrm{GA}_{3}$ & $14 \mathrm{~b}$ & - & - & - \\
\hline \multicolumn{5}{|l|}{ Pawnee } \\
\hline Control & - & $64 b^{x}$ & $2.71 \mathrm{~b}$ & $3.83 \mathrm{~b}$ \\
\hline $\mathrm{GA}_{3}$ & - & $44 \mathrm{a}$ & $1.28 \mathrm{a}$ & $2.65 \mathrm{a}$ \\
\hline
\end{tabular}

${ }^{\text {z}}$ Trees were treated in their "off" year with four sprays at biweekly intervals beginning early July with production of pistillate flowers being assessed the next spring at anthesis.

${ }^{y}$ ANOVA by least squares means with means within a column followed by the same letter are not significantly different $P=0.05$.

${ }^{x}$ ANOVA by least squares means. Means within a column followed by the same letter are not significantly different at $P=0.001$

ANOVA $=$ analysis of variance.

when applied within 3 to 7 weeks after full bloom. It appears to be within this timeframe that pistillate flower induction occurs, being completed when fruit are nearing maximum size (Amling and Amling, 1983; Wetzstein and Sparks, 1983), usually around early August. One or more molecular GA species trigger similar inhibitory activity in other fruit tree crops (Bangerth, 2009; Bertling and Bangerth, 1995) and grape (Vitis vinifera L.; Vasconcelos et al., 2009). It is unclear from the present study whether $\mathrm{GA}_{3}$ acts in pecan to prevent floral induction, to reverse induction processes, or both. It is also possible that it simply stops or retards physiological differentiation processes occurring during the early stages of physiological differentiation from the vegetative state.

Phase 2: Gibberellin 3 and return flowering of 'Pawnee' trees. 'Pawnee' trees treated with $\mathrm{GA}_{3}$ during their "off" bearing phase reduced pistillate flower production the next "on" year relative to the non-treated control (Table 2). $\mathrm{GA}_{3}$-treated canopies had fewer terminals displaying pistillate flowers to only $69 \%$ of the control, the average number of pistillate flowers per terminal to $47 \%$ of the control, and number of pistillate flowers per flower cluster to $69 \%$ of the control. Thus, $\mathrm{GA}_{3}$ not only reduces the number of terminal shoots on the tree that displayed pistillate flowers the next spring, but also reduces the number of florets in each floral cluster at anthesis. In apple, GAs inhibits floral bud formation when applied as a single application from before bloom to several weeks postbloom (Greene, 1989, 2000). It is possible that in pecan that either floral induction or initiation is sensitive to GAs over a period of several weeks with sensitivity depending on molecular GA species, concentration, and possibly cropload (as developing pecan fruit contain gibberellin-like substances and probably export these basipetally) and leaf area (Wood, 1982, 1984a).

Expt. 3: Influence of prohexadionecalcium on flowering of whole trees. Application of P-Ca, a metabolic inhibitor of GA synthesis (Evans et al., 1999), to “on"-phase trees increases return pistillate flowering in the next "off"-phase year when P-Ca is applied at high concentration during the pre-kernel filling phase of fruit development (Fig. 1). $\mathrm{P}-\mathrm{Ca}$, regardless of concentration, has little effect on the next year's pistillate flower crop if applied after initiation of kernel filling; however, a large curvilinear response with concentration affects the pistillate flower crop if application occurs during the pre-kernel filling period. $\mathrm{P}-\mathrm{Ca}$ at $500 \mathrm{mg} \cdot \mathrm{L}^{-1}$ is much more efficacious than $\mathrm{P}-\mathrm{Ca}$ at $250 \mathrm{mg} \cdot \mathrm{L}^{-1}$, resulting in $\approx 38 \%$ of terminal shoots displaying pistillate flowers compared with $\approx 2 \%$ for non-treated shoots. The ability of $\mathrm{GA}_{3}$ to reduce return flowering after "off" year use, and for the GA metabolic inhibitor (i.e., PCa) to increase flowering after "on" year use, indicates horticultural potential for manipulating endogenous GA concentrations and subsequent flowering. This responsiveness to P-Ca indicates that the ability of GAs to trigger reversion of floral induction or physiological differentiation within meristems is much greater before about the time of initiation of kernel filling than within a few weeks thereafter. Thus, efforts to manipulate flowering with GAs, or its metabolic inhibitors, are likely to be most successful before initiation of kernel filling.

Expt. 4: Influence of prohexadionecalcium and ethephon on flowering of whole trees. Ethephon's efficacy for promoting flowering in many angiosperm tree-fruit species (Byers and Carbaugh, 1991; Ferree and Schmidt, 2000; Greene, 2000; Luckwill and Child, 1978) and potential for regulating AB in apple (Bukovac et al., 2006) justified investigation of potential use for promotion of flowering in pecan. Success with P-Ca in these studies raises the possibility that combined use of P-Ca and ethephon might be especially promotive of flowering. Treatment of young pecan trees with $\mathrm{P}-\mathrm{Ca}$, ethephon, or a combination increased percentage of terminal shoots exhibiting pistillate flowers at anthesis the next spring over the nontreated control by $129 \%$ to $214 \%$ (Table 3 ). It is noteworthy that under conditions of this study, ethephon did not trigger either fruit or leaflet drop, but did cause fruit and leaf drop at a concentration twice that used here (data not included). The average number of fruit per terminal increased $67 \%$ and $78 \%$ in consequence of "Ethephon"

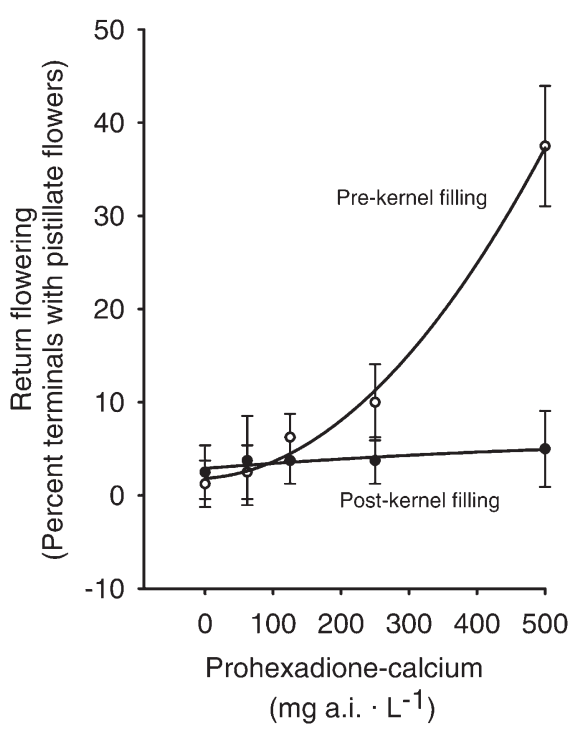

Fig. 1. Influence of spraying “on"-phase 'Pawnee' trees with prohexadione-calcium $(0,62.5,125$, 250 , and $500 \mathrm{mg}$ a.i./L) during either the prekernel filling or the post-kernel filling phase of fruit development (with kernel filling considered to initiate at the gel stage of seed development) on production of pistillate flowers at anthesis the next spring of an "off" year. Curvilinear regression for "\% of terminals with flowers" = $1.83+4.618 e^{-3} \mathrm{x}+1.326 e^{-4} x^{2}\left(R^{2}=0.99, \alpha \leq\right.$ $0.05)$ when applied pre-kernel filling and " $\%$ of terminals with flowers" $=2.906+2.906 \mathrm{x}-$ $3.14 e^{-6} x^{2}\left(R^{2}=0.81, \alpha \leq 0.05\right)$ when applied post-kernel filling.

and "P-Ca + Ethephon" treatments, respectively. The P-Ca treatment was most efficacious, increasing pistillate flower production by $156 \%$ over the nontreated control. Thus, both $\mathrm{P}-\mathrm{Ca}$ and ethephon increased percentage of terminal shoots flowering on young pecan trees, and both increased average number of pistillate flowers per terminal shoot; however, combining both bioregulators failed to elicit either an additive or a synergistic effect on flowering. It appears that in the case of number of fruit per terminal, $\mathrm{P}-\mathrm{Ca}$ at $500 \mathrm{mg} \cdot \mathrm{L}^{-1}$ is more efficacious than is ethephon at 100 $\mathrm{mg} \cdot \mathrm{L}^{-1}$ alone. Because P-Ca inhibits GA biosynthesis for 3 to 4 weeks after application (Evans et al., 1999) and has good acropetal movement, and at least some basipetal movement, it appears that GA synthesis is inhibited enough by P-Ca to enable increased pistillate flowering the next spring. This is most likely through facilitation of physiological differentiation during the early stages of floral initiation. These results further support a floral inhibitory role for GAs and a floral promoter role for ethylene (generated from metabolism of ethephon), thus indicating the possibility of either direct or indirect competition of GAs and ethylene at the same flowering-associated active site(s) or process(s).

Gibberellin $\mathrm{A}_{3}$ and possibly $\mathrm{GA}_{4+7}$ act as potent inhibitors of pistillate flower initiation in pecan, like with certain apple cultivars (Greene, 2000; Schmidt et al., 2009). These biochemicals therefore possess theoretical potential for reducing the magnitude 
of "on" phase flowering on floral bud exposed to a high endogenous GA environment during a portion of the pre-kernel filling phase of the previous "off"-phase year. In apple, it appears that $\mathrm{GA}_{7}$ is more inhibitory than is $\mathrm{GA}_{3}$ (Tromp, 1982). Perhaps different GAs vary in efficacy for inhibiting flowering in pecan and $\mathrm{GA}_{3}$ might not be the most active molecular species. These observations indicate that one or more GAs play a major role in regulation of $\mathrm{AB}$. This is supported in that 1) GA-like substances are present in pecan fruit (Wood, 1982, 1984a); 2) paclobutrazol, an inhibitor of GA biosynthesis, can increase flowering in pecan (Wood, 1984b); 3) the date of maximum rate of change in the pistillate flower action spectra of pecan is during the dough stage of seed development when GAs are likely present (Wood, 1995); and 4) the efficacious period for mechanical fruit thinning, to ensure return flowering, is about the same time as, or before, the dough stage of seed development (Smith et al., 1993) when GAs are likely to be high. A similar inhibitory activity in other crops, as reviewed by Dennis and Neilsen (1999), and by Bangerth (2009), further supports a floral inhibitory role for GAs.

\section{Study 2: Influence of cytokinin and auxin on flowering}

Expt. 1: Influence of benylamino purine, triiodobenzoic acid, and naphthaleneacetic acid on flowering of individual shoots when applied in the "on" phase. Treatment of "on"-phase terminal shoots of "on" trees with synthetic cytokinin- or auxin-type bioregulators potentially influences return flowering (Table 4). Because the next spring was an "off" year, trees produced few flowering shoots with only $13 \%$ of control shoots flowering the next spring. The percentage of subsequent season flowering shoots was unaffected by either TIBA or BA alone but greatly reduced by NAA. Surprisingly, shoot exposure to "TIBA + BA" led to $53 \%$ of terminal shoots flowering, this being a fourfold increase over the control. Certain bioregulators also influenced the number of pistillate flowers per flowering shoot with NAA and TIBA reducing and TIBA + BA slightly increasing pistillate florets per cluster. It is somewhat surprising that the inhibitory effect of TIBA, when used alone, is promotive when shoots receive both TIBA and BA. These findings hint that auxins are inhibitory to floral initiation in "on" years and that floral initiation processes within bud meristems of terminal shoots are influenced by a cytokinin-auxin interaction.

Expt. 2: Influence of benylamino purine, triiodobenzoic acid, and naphthaleneacetic acid on flowering of trees. Statistical analysis indicated a significant "bioregulator" treatment effect on return flowering characteristics of 'Pawnee' pecan with flowering being either reduced or increased depending on bioregulator treatment (Table 5). The number of pistillate flower clusters at anthesis the next spring and, arising from the terminal and lateral shoots originating from the previous growing season's terminal shoot, was unaffected by

Table 3. Influence of foliar sprays of gibberellic acid (ProGibb at $100 \mathrm{mg}$ a.i./L), prohexadione-calcium (P-Ca; Apogee; at $500 \mathrm{mg}$ a.i./L), and ethephon $\left(\mathrm{Ethrel}^{\circledR}\right.$, at $100 \mathrm{mg}$ a.i./L) on pistillate flower bloom the next spring of young 'Oconee' pecan trees. ${ }^{\mathrm{C}}$

\begin{tabular}{lcc}
\hline Treatment & $\begin{array}{c}\text { Percentage of terminal } \\
\text { shoots displaying } \\
\text { pistillate flowering (\%) }\end{array}$ & $\begin{array}{c}\text { Avg number of } \\
\text { pistillate flowers } \\
\text { per terminal (no.) }\end{array}$ \\
\hline Control & $7 \mathrm{a}^{\mathrm{y}}$ & $0.9 \mathrm{a}$ \\
P-Ca & $22 \mathrm{~b}$ & $2.3 \mathrm{c}$ \\
Ethephon & $20 \mathrm{~b}$ & $1.5 \mathrm{~b}$ \\
P-Ca + ethephon & $16 \mathrm{~b}$ & $1.6 \mathrm{~b}$ \\
\hline
\end{tabular}

${ }^{\mathrm{z}}$ Canopies received three biweekly applications beginning early June.

${ }^{y}$ Analysis of variance by least squares means. Means within a column and followed by the same letter are not significantly different at $P=0.001$ by Student's $t$ test.

Table 4. Influence of treating "on"-phase "Pawnee' terminal shoots with foliar sprays of plant bioregulators [N6'benzyladenine (BA, at $50 \mathrm{mg}$ a.i./L), 2,3,5-triiodobenzoic acid (TIBA, at $100 \mathrm{mg}$ a.i./L), and 1-naphthaleneacetic acid (NAA, K-Salt Fruit Fix at $10 \mathrm{mg}$ a.i./L)] of terminals on pistillate flower bloom the next spring. ${ }^{2}$

\begin{tabular}{lcc}
\hline Treatment & $\begin{array}{c}\text { Percentage of terminal } \\
\text { shoots displaying } \\
\text { pistillate flowers }(\%)\end{array}$ & $\begin{array}{c}\text { Number of pistillate } \\
\text { flowers per flowering } \\
\text { terminals (no.) }\end{array}$ \\
\hline Control & $13 \mathrm{~b}^{\mathrm{y}}$ & $3.0 \mathrm{~b}^{\mathrm{y}}$ \\
BA & $20 \mathrm{~b}$ & $3.0 \mathrm{~b}$ \\
TIBA & $12 \mathrm{~b}$ & $1.9 \mathrm{c}$ \\
NAA & $1 \mathrm{c}$ & $0.2 \mathrm{~d}$ \\
TIBA+ BA & $53 \mathrm{a}$ & $3.9 \mathrm{a}$
\end{tabular}

${ }^{\mathrm{z} C a n o p i e s ~ r e c e i v e d ~ t h r e e ~ b i w e e k l y ~ a p p l i c a t i o n s ~ b e g i n n i n g ~ e a r l y ~ J u l y . ~}$

${ }^{y}$ Analysis of variance by least squares means with means within a column followed by the same letter are not significantly different $P=0.05$ by Student's $t$ test.

Table 5. Influence of foliar sprays of NAA (at $10 \mathrm{mg}$ a.i./L), 2,3,5-triiodobenzoic acid (TIBA at $100 \mathrm{mg}$ a.i./L), and BA (at $50 \mathrm{mg}$ a.i./L) on subsequent season pistillate and staminate flowering of young 'Pawnee' trees.'

\begin{tabular}{lccc}
\hline & $\begin{array}{c}\text { Pistillate floral clusters } \\
\text { per previously treated } \\
\text { 1-year-old terminal }\end{array}$ & $\begin{array}{c}\text { Pistillate flowers per } \\
\text { previously treated } \\
\text { 1-year-old terminal (no.) }\end{array}$ & $\begin{array}{c}\text { Staminate catkin } \\
\text { triads per terminal } \\
\text { shoot (no.) }\end{array}$ \\
\hline Control & $1.9 \mathrm{~b}^{\mathrm{x}}$ & $6.8 \mathrm{~b}$ & $10.6 \mathrm{bc}$ \\
BA & $1.9 \mathrm{~b}$ & $5.4 \mathrm{c}$ & $11.2 \mathrm{ab}$ \\
TIBA & $2.1 \mathrm{~b}$ & $7.0 \mathrm{~b}$ & $9.8 \mathrm{c}$ \\
NAA & $0.4 \mathrm{c}$ & $1.1 \mathrm{~d}$ & $1.3 \mathrm{~d}$ \\
TIBA+ BA & $6.7 \mathrm{a}$ & $12.0 \mathrm{a}$ & $12.3 \mathrm{a}$ \\
\hline
\end{tabular}

"Trees were treated in a moderate "on" year $(\approx 40 \%$ of terminal shoots fruiting) with six sprays at biweekly intervals beginning early June with production of flowers being assessed at anthesis the next spring.

${ }^{y}$ Analysis of variance by least squares means. Means within a column followed by the same letter are not significantly different at $P=0.0001$ by Student's $t$ test.

${ }^{x}$ Mean number of pistillate floral clusters produced on the previously treated 1-year-old terminal. Means were $1.5 \mathrm{~b}$ versus $1.8 \mathrm{a}$ for "on" and "off" shoots, respectively. The mean number of pistillate flowers per previously treated 1-year-old terminal when terminal was $4.6 \mathrm{a}$ versus 5.0 a for "on" and "off" shoots, respectively. The mean number of staminate catkin triads per terminal shoot was 6.5 b versus 8.7 a for "on" and "off" shoots, respectively. The "on" versus "off" effect was significant at $P=0.001$ by analysis of variance for the number of pistillate floral clusters per previous 1-year-old terminal shoot and for the mean number of staminate catkin triads per terminal shoot.

TIBA or BA treatments but was substantially fewer when treated with NAA and greater when treated with TIBA + BA. This confirms the promotive effect observed in the previously described shoot-based study. The number of pistillate flower clusters was reduced to $21 \%$ of the control by NAA and increased 3.5fold by TIBA + BA. In the case of the total number of pistillate flowers per terminal and associated lateral shoots, TIBA alone had no effect, whereas NAA and BA alone reduced pistillate flowers and TIBA + BA substantially increased the number of pistillate flowers. The number of pistillate flowers was reduced to $16 \%$ of the control by NAA and $79 \%$ of the control for $\mathrm{BA}$, yet there was a 1.8 -fold increase by TIBA + BA. The number of staminate catkin triads per terminal shoot was unaffected by
TIBA or $\mathrm{BA}$ alone, reduced to $12 \%$ of the control for NAA alone, and was slightly increased $(16 \%)$ by TIBA + BA. Although shoot treatment with a combination of TIBA plus BA (i.e., TIBA + BA) led to several floral clusters per shoot, there were fewer flowers per cluster. The combination of TIBA + BA led to a pronounced positive synergism regarding floral initiation and subsequent flowering on a shoot basis with the ultimate expression of pistillate flowers being potentially influenced by interacting factors (e.g., the carbohydrate environment). This synergism is suggestive of partial regulation of floral initiation processes governed by the relative auxin-cytokinin balance with a high cytokinin:auxin ratio enabling expression of pistillate and staminate flower buds during anthesis the next spring. 
There was a significant effect on the number of pistillate flower clusters per previously treated 1-year-old terminals and the number of staminate catkin triads per terminal shoot but no effect on the number of pistillate flowers per previously treated 1-year-old terminal (Table 5 , see footnote). For the two former parameters, values were slightly less for shoots previously in the "on" bearing phase than in the "off" bearing phase. This small difference in return flowering in relation to previous-year bearing phase of treated shoots is likely because trees were young, and differences might have been much greater in older more physiologically mature trees.

\section{Potential as tools for mitigation of alternate bearing in pecan}

The present study illustrates that several commercially available bioregulators exhibit potential as horticultural tools for mitigation of $\mathrm{AB}$ through regulating pistillate flower initiation and subsequent flowering. It is clear that $\mathrm{GA}_{3}, \mathrm{GA}_{4+7}$, and NAA possess theoretical use as floral inhibitors and are useful for reducing return flowering in otherwise "on"phase trees when canopies are properly exposed during the previously "off"-phase season. Conversely, P-Ca, ethephon, and BA + TIBA possess theoretical use as floral promoters and therefore potential for increasing return flowering of otherwise "off"-phase trees when canopies are properly exposed during the previous "on"-phase season. This raises the possibility of bioregulator-based regulation of floral initiation in commercial orchards by orchard managers by using GAs and/or NAA (and probably other auxins as well) in severe "off" years to decrease flowering during the subsequent "on" phase the next spring and $\mathrm{P}-\mathrm{Ca}$, ethephon, or BA, and possibly an auxin inhibitor during the "on"-phase year to increase return flowering in the subsequent "off"-phase year. However, the development of bioregulator-based $\mathrm{AB}$ control strategies in orchards is problematic in that success depends on considerable research to identify the appropriate bioregulator mix, rate, and timing in relation to tree cropload and on satisfying regulatory constraints.

\section{Implications regarding flowering in pecan}

The ability of NAA to inhibit flowering in pecan is consistent with a "second messenger" role, as presented by Bangerth (2006), for auxins (e.g., indole-3-acetic acid) as an inhibitor of flowering in perennial trees with endogenous auxin being substantially controlled by both GA concentration and molecular species within developing fruit. In pome crops, GA-treated fruit are strong auxin exporters (Bangerth, 2006), and developing seeds appear to play a key role in floral induction and AB (Chan and Cain, 1967; Dennis and Neilsen, 1999). Thus, the apparent high concentration of GAs in developing pecan fruit (Wood, 1982) might trigger auxin exportation sufficient to either inhibit or reverse pistillate flower initiation processes occurring within bud meristems.
It is noteworthy that neither BA nor TIBA alone positively influence pistillate flower initiation or production but are promotive in combination. This might be because auxin regulates cytokinin concentration and vice versa (Nordstrom et al., 2004), thus enabling relatively homeostatic crosstalk because the two phytohormones regulate plant developmental events. In the absence of TIBA, it might be that enough auxin is produced by pecan organs (i.e., developing fruit, apices, and young foliage) to rapidly metabolize BA (or other cytokinins) to non-bioactive forms, because auxin (e.g., IAA) can rapidly upregulate cytokinin oxidase and block cytokinin biosynthetic pathways, thus reducing the endogenous cytokinin environment to which buds are exposed the previous year when florally induced meristems were subject to reversion during the physiological differentiation phase of floral initiation. It is possible that BA alone did not enhance pistillate flowering because other necessary long-distance signals (e.g., ethylene and possibly others) were not quantitatively or qualitatively compatible with increased flowering, or its rapid deactivation prevents an effect on floral initiation processes. The fact that floral initiation increases with application of BA in combination with TIBA indicates that BA is potentially an active cytokinin molecular species for floral initiation in pecan.

Auxins (e.g., NAA) and cytokinins (e.g., BA) are thought to act somewhere in the physiological differentiation stage downstream of activation of key floral induction genes (Horvath, 2009), as activated by florigen (i.e., a leaf produced phloem mobile $20-\mathrm{kDa}$ protein that moves to bud meristems and apices to induce the floral process; Shalit et al., 2009; Zeevaart, 2008). Findings here appear consistent with a positive effect of TIBA, a potent auxin transport inhibitor, observed for flowering in other fruit tree species and a promotive effect of cytokinin on flowering in several perennial tree species (Bangerth, 2009). Because auxin can inhibit cytokinin biosynthesis (Nordstrom et al., 2004), it is possible that flower initiation processes in pecan are not only substantially regulated by GAs through inhibition, as described previously, but also through cytokinins' promotive effects. If so, then the promotive effect of cytokinin is potentially subject to modulation by auxin from young foliage and fruit. Thus, a cytokininGA balance, or equilibrium, appears to regulate "on"-phase pistillate flower initiation with equilibrium potentially regulated by a cytokinin-auxin interaction with either auxin or ethylene acting as quantitative "longdistance" signals (Bangerth, 2009). Several findings support this possibility, including those by Palni et al., (1988) in which increasing endogenous auxin reduces endogenous cytokinin through effects on cytokinin oxidase activity; by Ito et al. (2001) in which decreasing auxin leads to increased bud cytokinin; by $\mathrm{Li}$ et al. (2003) in which removing the shoot apex (a rich source of auxin) greatly increases endogenous cytokinin concentration; by Chunjian and Bangerth et al. (2000) in which they found a mutually antagonizing interaction between cytokinin and auxin; by Nordstrom et al. (2004) in which auxin regulates cytokinin levels and vice versa; and by Rashotte et al. (2005) in which cytokinin can trigger biosynthesis of ethylene. Thus, the present study supports the idea that a cytokinin-GA balance, as thought to operate in Vitis spp. (Vasconcelos et al., 2009), regulates the early stages of floral initiation in pecan, and auxin and ethylene modulates this balance.

\section{Conclusions}

Findings here support the theory that the autonomous floral pathway dominates floral initiation process acting between floral induction (i.e., processes required for evocation) and vernalization (inductive process requiring low temperature) or evocation (processes required for irreversible commitment to initiate flower primordia) occurring before actual flower development (processes occurring from after evocation until anthesis). The present study supports conclusions by others, working with different crops, that endogenous factors regulating at least one flowering phase includes GAs, auxin (indole-3-acetic acid), ethylene, and cytokinins. These phytohormones collectively act and interact as a long-distance "level-two floral signal" to regulate flowering through chromatin modification (Bangerth, 2009) after florigen (i.e., florigen as the "level-one floral signal") triggered chromatin modification that initiates floral induction physiology. Additionally, sugar signaling also plays key roles in developmental processes such as flowering (Gibson, 2005), in which complex interplay between phytohormones and sugars affects each other (Leon and Sheen, 2003). In the case of pecan, it is clear that sugars are intimately involved in one or more processes controlling floral initiation (Smith and Waugh, 1938; Sparks, 1974, 1975; Wood, 1989, Wood et al., 2004; Worley 1979a, $1979 b)$ with their role being expressed in association with successful vernalization and subsequent floral evocation (Wetzstein and Sparks, 1983; Wood, 1989, 1995); however, sugars are not the sole factor driving pistillate flower initiation nor AB (Rohla et al., 2007a, 2007b; Smith et al., 2007). Timely use of bioregulators may provide the means of affecting key downstream floral initiation processes through effects on sugar-based chromatin modulation (Gibson, 2003, 2005; Koch, 1996; Li et al., 2003) such as that occurring during floral vernalization and evocation.

Although the present study does not quantify endogenous phytohormone concentrations, nor presence of associated receptors, in association with floral primordia or their environment, results nevertheless provide evidence that GAs, auxins, ethylene, and cytokinin influence floral initiation in pecan; thus, at least one key process is largely controllable by the action and/or interaction of one or more molecular species of these phytohormones. It is therefore postulated that pecan's post-induction phase of pistillate flower initiation is largely regulated by the endogenous "cytokinin-GA" 
environment to which young bud meristems are exposed during late spring and early summer before kernel filling. This cytokinin-GA balance appears to be subject to modulation by ethylene and auxin exported from foliage and/ or fruit and/or influenced by tree and/or organ stress. The cytokinin-GA balance likely affects chromatin-related activities within meristematic cells as well as downstream changes in floral initiation processes needed to prepare pistillate floral primordia for vernalization and evocation.

When the results of the present study are considered within the context of finding by Zeevaart (2008) on the role of florigen an initiating floral signal, Bangerth (2009) on the role of phytohormones in the primordial environment, and others regarding the role of carbohydrate reserves and their effect on primordia (Koch, 1996; Leon and Sheen, 2003; Li et al., 2003; Wood, 1989), it appears that pistillate flower initiation in pecan involves three distinct phases of chromatin modification before new flowers appear in early spring. The following is a proposed model explaining initiation of pistillate flowers in pecan.

Three sequential phases of chromatin modification control pistillate flower initiation, beginning with 1) a foliage produced phloem translocated florigen acting as a firstlevel signal to initiate phase-one chromatinmodifying inductive processes in young bud primordia; 2) then phase-two chromatin modification regulated by translocated phytohormones, from foliage and/or fruit, acting in the primordia environment during early postinduction as a "cytokinin-GA ratio" based second-level signal subject to modulation by auxin and ethylene; and 3) finally phase-three chromatin modification regulated by concentration of one or more non-structural carbohydrates (e.g., sucrose) acting in the primordia environment during vernalization as a thirdlevel signal enabling floral development in preparation for anthesis.

This model identifies a testable theory possessing three distinct stages as potential candidates for horticultural intervention for controlling pistillate flowering. It also provides a basis for future research toward better understanding of flowering and $\mathrm{AB}$ processes and subsequent development of horticultural tools and strategies enabling greater year-toyear stability in nutmeat yield and quality from trees and orchards of pecan and other woody perennial polycarpic species.

\section{Literature Cited}

Amasino, R. 2010. Seasonal and developmental timing of flowering. Plant J. 61:1001-1013.

Amling, H.J. and K.A. Amling. 1983. Physiological differentiation of pistillate flowers of pecan and cold requirements for their initiation. J. Amer. Soc. Hort. Sci. 108:195-198.

Bangerth, F. 2006. Flower induction in perennial fruit trees: Still an enigma? Acta Hort. 727:177-195.

Bangerth, F., C.-J. Li, and J. Gruber. 2000. Mutual interaction of auxin and cytokinins in regulating correlative dominance. Plant Growth Regulation 32:205-217.

Bangerth, K.F. 2009. Floral induction in mature, perennial angiosperm fruit trees: Similarities and discrepancies with annual/biennial plants and the involvement of plant hormones. Sci. Hort. 122:153-163.

Barnett, J. and E.A. Mielke. 1981. Alternate bearing: A re-evaluation. Pecan South 8:20-23.

Bertling, I. and F. Bangerth. 1995. Changes in hormonal pattern of the new growth of Sclerocarya birrea after rejuvenation treatment with $\mathrm{GA}_{3}$ and heading back. Gartenbauwissenschaf 60:119-124.

Bukovac, M.J., P. Sabbatini, and P.G. Schwallier. 2006. Modifying alternate bearing of spur-type 'Delicious' apple with ethephon. HortScience 41:1606-1611.

Byers, R.E. and D.H. Carbaugh. 1991. Effect of chemical thinning sprays on apple fruit set. HortTechnology 1:41-48.

Chan, B.G. and J.C. Cain. 1967. The effect of seed formation on subsequent flowering in apple. Proc. Amer. Soc. Hort. Sci. 91:63-68.

Dennis, F.G., Jr. and J.C. Neilsen. 1999. Physiological factors affecting biennial bearing in tree fruit: The role of seeds in apple. Hort Technology 9:317-322.

Evans, J.R., R.R. Evans, C.L. Regusci, and W. Rademacher. 1999. Mode of action, metabolism, and uptake of BAS- $125 \mathrm{~W}$, prohexadionecalcium. HortScience 34:1200-1201.

Ferree, D.C. and J.C. Schmidt. 2000. Chemical thinning 'Fuji' apple in the midwest. Fruit Var. J. 54:61-67.

Finn, G.A., A.E. Straszewski, and V. Peterson. 2007. A general stage key for describing trees and woody plants. Ann. Appl. Biol. 151:127-131.

Gibson, S.I. 2003. Sugar and phytohormone response pathways: Navigating a signaling network. J. Expt. Bot. 55:253-264.

Gibson, S.I. 2005. Control of plant development and gene expression by sugar signaling. Curr. Opin. Plant Biol. 8:93-102.

Greene, D.W. 1989. Gibberellins influence fruit set, fruit quality, and return bloom of apples. J. Amer. Soc. Hort. Sci. 114:619-625.

Greene, D.W. 2000. Reducing floral initiation and return bloom in pome fruit trees: Applications and implications. Hort Technology 10:740743.

Horvath, D. 2009. Common mechanisms regulate flowering and dormancy. Plant Sci. 177:523531.

Hudson, W., J. Brock, S. Culpepper, W. Mitchem, and L. Wells. 2007. Georgia pecan pest management guide. Georgia Coop. Ext. Serv. Bul. No. 841.

Ito, A., H. Hayama, Y. Kashimura, and H. Yoshioka. 2001. Effect of maleic hydrazide on endogenous cytokinin contents in lateral buds, and its possible role in flower bud formation on the Japanese pear shoot. Sci. Hort. 87:199-205.

Koch, K.E. 1996. Carbohydrate-modulated gene expression in plants. Annu. Rev. Plant Physiol. Plant Mol. Biol. 47:509-540.

Leon, P. and J. Sheen. 2003. Sugar and hormone connections. Trends Plant Sci. 8:110-116.

Li, C. and F. Bangerth. 2003. Stimulatory effect of cytokinins and interaction with IAA on the release of lateral buds of pea plants from apical dominance. J. Plant Physiol. 160:1059-1063.

Li, C.Y., D. Weiss, and E.E. Goldschmidt. 2003. Effects of carbohydrate starvation on gene expression in citrus root. Planta 217:11-20.

Looney, N.E., R.P. Pharis, and M. Noma. 1985. Promotion of flowering in apple trees with gibberellins $\mathrm{A}_{4}$ and $\mathrm{C}-3$ epi-gibberellin $\mathrm{A}_{4}$. Planta 165:292-294.

Luckwill, L.C. and R.D. Child. 1978. Part tree [sic] thinning of apples with CEPA. Acta Hort. 80: 271-274.
Nordstrom, A., P. Tarkowski, D. Tarkowska, R. Norbaek, C. Astot, K. Dolzal, and G. Sandberg. 2004. Auxin regulation of cytokinin biosynthesis in Arabidopsis thaliana: A factor of potential importance for auxin-cytokinin-regulated development. Proc. Natl. Acad. Sci. USA 101: 8039-8044.

Olsen, O.-A. 2001. Endosperm development: Cellularization and cell fate specification. Annu. Rev. Plant Physiol. Plant Mol. Biol. 52:233-267.

Palni, L.M., L. Burch, and R. Horgan. 1988. The effect of auxin concentration on cytokinin stability and metabolism. Planta 174:231-234.

Rashotte, A.M., H.S. Chae, B.B. Maxwell, and J.J. Kieber. 2005. The interaction of cytokinin with other signals. Physiol. Plant. 123:184-194.

Rohla, C.T., M.W. Smith, and N.O. Maness. 2007a. Influence of cluster thinning on return bloom, nut quality, and concentrations of potassium, nitrogen, and non-structural carbohydrates in pecan. J. Amer. Soc. Hort. Sci. 132:158-165.

Rohla, C.T., M.W. Smith, N.O. Maness, and W. Reid. 2007b. A comparison of return bloom and nonstructural carbohydrates, nitrogen, and potassium concentrations in moderate and severe alternate-bearing pecan cultivars. J. Amer. Soc. Hort. Sci. 132:172-177.

Schmidt, T., D.C. Elfving, J.R. McFerson, and M.D. Whiting. 2009. Crop load overwhelms effects of gibberellic acid and ethephon on floral initiation in apple. HortScience 44:1900-1906.

Shalit, A., A. Rozman, A. Goldschmidt, J.P. Alvarrez, J.L. Bowman, Y. Eshed, and E. Lifschitz. 2009. The flowering hormone florigen functions as a general systemic regulator of growth and termination. Proc. Natl. Acad. Sci. USA 106:8392-8397.

Smith, C.L. and J.G. Waugh. 1938. Seasonal variations in the carbohydrate and nitrogen content of roots of bearing pecan trees. J. Agr. Res. 57:449-460.

Smith, M.W. and J.C. Gallott. 1990. Mechanical thinning of pecan fruit. HortScience 25:414-416.

Smith, M.W., W. Reid, B. Carroll, and B. Cheary. 1993. Mechanical fruit thinning influences fruit quality, yield, return fruit-set, and cold injury of pecan. HortScience 28:1081-1084.

Smith, M.W., C.T. Rohla, and N.O. Maness. 2007. Correlations of crop load and return bloom with root and shoot concentrations of potassium, nitrogen, and nonstructural carbohydrates in pecan. J. Amer. Soc. Hort. Sci. 132:158-165.

Sparks, D. 1974. The alternate fruit bearing problem in pecans. Northern Nut Growers' Assn. 47:145-158.

Sparks, D. 1975. Alternate fruit bearing-A review. Pecan South 2:44-65.

Tromp, J. 1982. Flower bud formation in apple as affected by various gibberellins. J. Hort. Sci. $57: 277-282$.

Vasconcelos, C.M., M. Greven, C.C. Winefield, M.C.T. Trought, and V. Raw. 2009. The flowering process of Vitis vinifera: A review. Amer. J. Enol. Viticult. 60:411-434.

Wetzstein, H.Y. and D. Sparks. 1983. The morphology of pistillate flower differentiation in pecan. J. Amer. Soc. Hort. Sci. 108:997-1003.

Wilkie, J.D., M. Sedgley, and T. Olesen. 2008. Regulation of floral initiation in horticultural trees. J. Expt. Bot. 59:3215-3228.

Wood, B.W. 1982. Gibberellin-like substances in developing fruits of pecan. HortScience 17:70-71.

Wood, B.W. 1984a. Free and bound abscisic acid and free gibberellin-like substances in pecan kernel tissue during seed development. J. Amer. Soc. Hort. Sci. 109:626-629.

Wood, B.W. 1984b. Influence of paclobutrazol on selected growth and chemical characteristics of 
young pecan seedlings. HortScience 19:837839.

Wood, B.W. 1989. Pecan production responds to root carbohydrates and rootstock. J. Amer. Soc. Hort. Sci. 114:223-228.

Wood, B.W. 1991. Alternate bearing in pecan, p. 180-190. In: Wood, B.W. and J.A. Payne (eds.). Pecan husbandry: Challenges and opportunities. First National Pecan Workshop Proc., U.S. Department of Agriculture, Agricultural Research Service, ARS-96.

Wood, B.W. 1995. Relationship of reproductive and vegetative characteristics of pecan to previous- season fruit development and post-ripening foliation period. J. Amer. Soc. Hort. Sci. 120: 635-642.

Wood, B.W. 2003. Pecan production in North America. Southwestern Entomologist 27: $1-19$.

Wood, B.W., P.J. Conner, and R.E. Worley. 2003. Relationship of alternate bearing intensity in pecan to fruit and canopy characteristics. HortScience 38:361-366.

Wood, B.W., P.J. Conner, and R.E. Worley. 2004. Insight into alternate bearing of pecan. Acta Hort. 636:617-629.
Wood, B.W. and J.L. McMeans. 1981. Carbohydrate changes in various organs of bearing and nonbearing pecan trees. J. Amer. Soc. Hort. Sci. 106:758-761.

Worley, R.E. 1979a. Pecan yield, quality, nutlet set, and spring growth as a response to time of fall defoliation. J. Amer. Soc. Hort. Sci. 104:192194.

Worley, R.E. 1979b. Fall defoliation date and seasonal carbohydrate concentration of pecan wood tissue. J. Amer. Soc. Hort. Sci. 104:195-199.

Zeevaart, J.A.D. 2008. Leaf-produced floral signals. Curr. Opin. Plant Biol. 11:541-547. 